\title{
DETERMINATION OF THE BOROWIEC SLR STATION COORDINATES
}

\author{
S. Schillak \\ Space Research Centre of the Polish Academy of Sciences \\ Astrogeodynamic Observatory \\ 4. Drapalka Str., Borowiec, 62-035 Kornik, Poland
}

(Received 31 July, 2002)

\begin{abstract}
The paper presents results of determination of the position of the Borowiec SLR (7811) station in the period 1997-2000. The coordinates were calculated by GEODYN-II orbital program on ALPHA computer in Borowiec Observatory from LAGEOS-1 and LAGEOS-2 monthly arcs of thirteen fixed SLR stations in ITRF97 coordinates system. The accuracy of the monthly orbital arcs was better than $\pm 2 \mathrm{~cm}$. The stability of the Borowiec SLR geocentric and topocentric coordinates in the whole period was equal to $\pm 1.5 \mathrm{~cm}$. Some vertical systematic variations on the level of a few centimetres were detected. A similar effect was observed in the range bias. The final geocentric coordinates of the Borowiec SLR station from 1997-2000 differ from those in ITRF97 system by a few millimetres.

Key words: satellite geodesy, geodynamics, satellite laser ranging.
\end{abstract}

PACS number(s): 91.10.Jf

\section{INTRODUCTION}

Determination of the station coordinates is a one of the important task of satellite laser ranging (SLR). The Borowiec SLR station (ILRS No 7811) performed the satellite laser observations from more than 10 years on the good level of quality and quantity of data. The Borowiec SLR geocentric coordinates in the International Terrestrial Reference Frame 1997 system (ITRF97) were determined from results of observations of two satellites LAGEOS-1 and LAGEOS-2 for the period of four years $1997-2000$.

\section{FIXED STATIONS}

Thirteen fixed stations in ITRF97 coordinates system [1] were used in each year for LAGEOS-1 and LAGEOS-2 orbits determination. The choice of the stations have been performed on the base of their good quality and quantity of data, a good ITRF coordinates stability, and second space technique on site (GPS or VLBI). The list of the stations is as following: McDonald (7080), Yarragadee (7090), Greenbelt (7105), Monument Peak (7110), Heleakala (7210) to September 1999 and then Thaiti (7124) from January 2000, Arequipa (7403), Grasse (7835), Potsdam (7836). Simosato (7838) in 19971998, 2000, Koganei (7328) in 1999, Graz (7839), Herstmonceux (7840), Orroral (7843) to November 1998 and Mount Stromlo (7849) from December 1998, Wettzell (8834).

\section{ORBITAL ANALYSIS}

The orbital program NASA GEODYN-II, version 9903 [2] was used for the analysis presented in this paper.
All calculations were performed on ALPHA computer in Borowiec Observatory. The force model and parameters used in the calculations were the same as in the papers [3-5]. Number of normal points and orbital RMS for each arc from results of these 13 stations and Borowiec are presented in Table 1 . The Borowiec range biases and orbital RMS independently for both satellites and each month were determined in the first step of the orbital analysis (Table 2). Very good agreement of range biases between results from satellites LAGEOS-1 and LAGEOS-2 indicate lack of significant differences between both orbits and properly work of the orbital program. Geocentric coordinates of the Borowiec SLR station from residuals of both satellites were calculated in the second step. The results for epoch 1997.0 for every year are presented in Table 3 , more detailed results for every month in topocentric coordinates are shown in Fig. 1.

\section{CONCLUSIONS}

The results presented in this paper show very good agreement with ITRF97 coordinates, which are mainly based on Borowiec GPS observations (BOR1). Only in vertical component is visible some wave in the period 1997-1999 but not in 2000. It is probably result of systematic biases of Borowiec SLR station. Mean range bias is below $1 \mathrm{~cm}$ in the whole four years period. The mean stability of the Borowiec coordinates is equal $1.5 \mathrm{~cm}$, but in the last two years 1999-2000 is observed significantly improvement of coordinates stability due to more number of normal points and better quality of the data. The accuracy of orbit determination is very stable in all four years $1997-2000$ and equal to $\pm 18 \mathrm{~mm}$. 

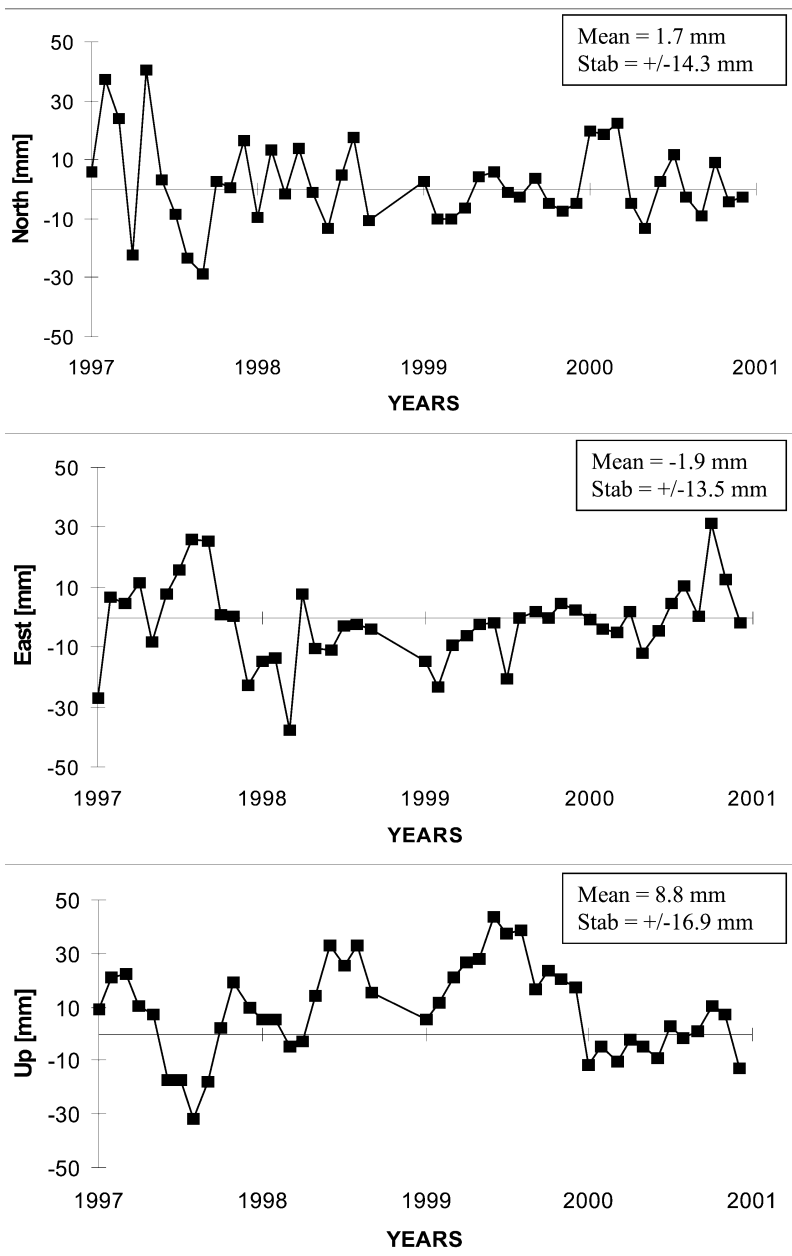

Fig. 1. Coordinates of Borowiec SLR station in ITRF97 system for the period 1997-2000.

\begin{tabular}{|l|ll|ll|ll|ll|}
\hline \multicolumn{1}{|c|}{ MONTH } & \multicolumn{2}{|c|}{1997} & \multicolumn{2}{|c|}{1998} & \multicolumn{2}{c|}{1999} & \multicolumn{2}{c|}{2000} \\
\hline JANUARY & 5094 & 21 & 8751 & 20 & 7475 & 18 & 8138 & 20 \\
\hline FEBRUARY & 5473 & 17 & 10468 & 19 & 6898 & 17 & 7279 & 17 \\
\hline MARCH & 6138 & 18 & 9739 & 18 & 8733 & 20 & 6563 & 17 \\
\hline APRIL & 9610 & 17 & 7887 & 16 & 7829 & 19 & 6928 & 19 \\
\hline MAY & 8007 & 17 & 7782 & 14 & 8666 & 18 & 8847 & 20 \\
\hline JUNE & 6742 & 16 & 7059 & 17 & 7767 & 17 & 7863 & 19 \\
\hline JULY & 6985 & 16 & 9468 & 17 & 8888 & 17 & 6807 & 18 \\
\hline AUGUST & 6022 & 14 & 9623 & 20 & 8479 & 17 & 9216 & 17 \\
\hline SEPTEMBER & 8956 & 17 & 8023 & 20 & 9052 & 16 & 8542 & 18 \\
\hline OCTOBER & 9138 & 18 & 7838 & 21 & 10918 & 18 & 6863 & 17 \\
\hline NOVEMBER & 7518 & 17 & 5981 & 19 & 9499 & 20 & 7106 & 19 \\
\hline DECEMBER & 7496 & 20 & 5687 & 17 & 7273 & 19 & 7802 & 18 \\
\hline TOTAL & 87179 & 17 & 98306 & 18 & 101477 & 18 & 91954 & 18 \\
\hline
\end{tabular}

Table 1. Orbital arcs - number of normal points and orbital RMS (mm). 


\begin{tabular}{|c|c|c|c|c|}
\hline YEAR & SATELLITE & $\begin{array}{c}\text { NUMBER } \\
\text { NP }\end{array}$ & $\begin{array}{c}\text { RANGE BIAS } \\
\mathrm{mm}\end{array}$ & $\begin{array}{c}\text { ARC RMS } \\
\mathrm{mm}\end{array}$ \\
\hline \multirow{2}{*}{1997} & LAGEOS-1 & 867 & $-4 \pm 9$ & 22 \\
& LAGEOS-2 & 475 & $-8 \pm 19$ & 26 \\
\hline \multirow{2}{*}{1998} & LAGEOS-1 & 968 & $-12 \pm 10$ & 24 \\
& LAGEOS-2 & 656 & $-14 \pm 10$ & 16 \\
\hline \multirow{2}{*}{1999} & LAGEOS-1 & 1904 & $-18 \pm 10$ & 20 \\
& LAGEOS-2 & 1267 & $-14 \pm 8$ & 18 \\
\hline \multirow{2}{2}{000} & LAGEOS-1 & 834 & $0 \pm 7$ & 18 \\
& LAGEOS-2 & 831 & $1 \pm 12$ & 17 \\
\hline $1997-2000$ & LAGEOS-1 & 4573 & $-9 \pm 11$ & 22 \\
& LAGEOS-2 & 3229 & $-9 \pm 13$ & 20 \\
\hline
\end{tabular}

Table 2. Results of the orbital arcs for Borowiec SLR (7811) station.

\begin{tabular}{|c|c|c|c|c|c|c|c|}
\hline Year & $\begin{array}{c}X \\
\mathrm{~mm}\end{array}$ & $\begin{array}{c}Y \\
\mathrm{~mm}\end{array}$ & $\begin{array}{c}Z \\
\mathrm{~mm}\end{array}$ & $\begin{array}{c}\text { North } \\
\mathrm{mm}\end{array}$ & $\begin{array}{c}\text { East } \\
\mathrm{mm}\end{array}$ & $\begin{array}{c}\mathrm{Up} \\
\mathrm{mm}\end{array}$ & $\begin{array}{c}\sigma \\
\mathrm{mm}\end{array}$ \\
\hline 1997 & $841 \pm 13$ & $501 \pm 17$ & $027 \pm 25$ & $4 \pm 23$ & $3 \pm 17$ & $1 \pm 18$ & 19 \\
\hline 1998 & $856 \pm 15$ & $486 \pm 18$ & $033 \pm 14$ & $-1 \pm 13$ & $-15 \pm 19$ & $13 \pm 14$ & 16 \\
\hline 1999 & $862 \pm 7$ & $497 \pm 9$ & $041 \pm 10$ & $-3 \pm 6$ & $-6 \pm 9$ & $24 \pm 11$ & 9 \\
\hline 2000 & $838 \pm 10$ & $499 \pm 12$ & $023 \pm 8$ & $4 \pm 12$ & $3 \pm 11$ & $-3 \pm 7$ & 10 \\
\hline $1997-2000$ & $848 \pm 14$ & $497 \pm 13$ & $031 \pm 17$ & $2 \pm 14$ & $-2 \pm 14$ & $9 \pm 17$ & 15 \\
\hline
\end{tabular}

Table 3. Coordinates of Borowiec SLR (7811) in ITRF97 system for epoch 1997.0 (ITRF97: $X=3738332.844 \mathrm{~m}$, $Y=1148246.498 \mathrm{~m}, Z=5021816.023 \mathrm{~m})$.

\section{ACKNOWLEDGMENTS}

Thanks are due to the NASA Space Geodesy Branch for giving me the access to the program GEODYN-II and all the authors of this excellent program without which this study could not have been done. I wish to thank my wife Danuta Schillak and Mr Tomasz Celka, M. Sc. for his assistance in preparing the data for the program GEODYN-II and in the calculations. The work was supported by the State Committee for Scientific Research (KBN) within grant No. 9T12E 02419.
[1] C. Boucher, Z. Altamini, P. Sillard, The 1997 International Terrestrial Reference Frame (ITRF97), IERS Technical Note 27, Obs. De Paris, Paris, (1999).

[2] J. J. McCarthy, D. Moore, S. Luo, S. B. Luthcke, D. E. Pavlis, S. Rowton, L. S. Tsaousi, GEODYN-II, Vol. 1-5, Hughes STX Systems Corporation, Greenbelt, MD, (1993).

[3] S. Schillak, Determination of the Borowiec SLR Coordi- nates, Proc. 12th International Workshop on Laser Ranging, Matera, 13-17.11.2000, ed. G. Bianco, V. Luceri, Matera, Italy (2001).

[4] S. Schillak, M. Kuźmicz-Cieślak, E. Wnuk, Artificial Satellites (Warsaw), 36, No. 3, 85 (2001).

[5] E. Wnuk, S. Schillak, M. Kuźmicz-Cieślak, Adv. Space Research 30, 413 (2002). 


\title{
ВИЗНАЧЕННЯ КООРДИНАТ СУПУТНИКОВОЇ ЛАЗЕРНОЇ ВІДДАЛЕМІРНОЇ СТАНЩІї В БОРОВЩІ
}

\author{
С. Шилак \\ Иентр космічних досліджень Польськой академіӥ наук \\ Астрогеодинамічна обсерваторіл Боровєи, \\ вул. Драпалка, 4, 62-035 Корнік, Польща
}

Подано результати з визначення розташування станщії в Боровщі (7811) за період 1997-2000 pp. Kоopдинати розраховано в системі ITRF97 за допомогою програми GEODYN-II на компютері класу АЛЬФА в Боровецкій обсерваторії за результатами спостережень супутників LAGEOS-1 та LAGEOS-2 з тринадщяти лазерних станщій. Точність орбітальних дуг була нижчою за \pm 2 см. Стабільність геоцентричних та топоцентричних координат станпії в Боровџі протягом усього періоду становила \pm 1.5 см. Помічено деякі систематичні вертикальні коливання в межах кількох сантиметрів. Подібний ефект також зафіксовано для систематичного зсуву виміряної віддалі. Остаточні координати станџії в Боровпі за період 1997-2000рp. відрізняються від визначених у системі ITRF97 на декілька міліметрів. 